ROCZNIKI HUMANISTYCZNE

Tom LXIX, zeszyt $6-2021$

DOI: https://doi.org/10.18290/rh21696-10

BEATA WÓJTOWICZ

\title{
CULTURAL NORMS OF GREETINGS IN THE AFRICAN CONTEXT*
}

\section{INTRODUCTION}

Knowledge of a foreign language facilitates communication. Therefore, foreigners try to learn at least a few words and some simple, useful expressions, including greetings, when visiting a new country. Everyone is aware that greetings play an important role and are frequently used in everyday social interactions all over the world. Appropriate greeting-related behaviour may be crucial for the establishment and maintenance of interpersonal relationships. However, what counts more than vocabulary is the ability to employ proper socio-cultural norms in language communication. One often forgets that knowing the words or fixed expressions of a language is not enough to hold a proper conversation.

There is much more to a successful conversation than words. When talking, people make use of all sorts of other, non-verbal expressions and behaviour. There are also all sorts of cultural norms and values that one has to obey when using a foreign language as there may be fundamental communication and discourse differences between one language and another. For example, we need to know what we can talk about and what topics are considered taboo by our interlocutors; who should speak first in a particular situation

Dr hab. BeAta WóJTowicz-adiunkt w Katedrze Języków i Kultur Afryki Wydziału Orientalistycznego Uniwersytetu Warszawskiego; adres do korespondencji: Uniwersytet Warszawski, ul. Krakowskie Przedmieście 26/28, 00-927 Warszawa; e-mail: b.wojtowicz@uw.edu.pl. ORCID: https://orcid.org/0000-0002-8819-3219.

${ }^{*}$ The research was funded by the Polish National Science Center (NCN) grant nr 2018/31/B/ HS2/01114. 
and social context, and how to linguistically behave in order not to offend anyone. Thus, we need to be aware that every community has its own culture-specific speech practices and norms that are applied during interaction. It is not only the language that is different but also speakers' behaviour, norms, beliefs, values and priorities. If foreign language speakers are not familiar with these constraints it may lead to cultural conflicts, that is the use of one code in a cultural and social context of the other (Batibo).

On the other hand, there are also similarities, particular behaviours and norms that are shared among different linguistic communities. Thus, such groups may share similar communicative practices. Ameka and Breedveld (2004) identify the so-called West African cultural area, in which different linguistic communities share the same norms, such as being silent during a meal-the norm is contradictory to the one that is shared in the Western culture where a meal is perceived as a good opportunity for a family conversation. ${ }^{2}$ There is also a left-hand taboo shared with many other African communities but again not with the Western world. Since the left hand is thought of as a dirty hand meant for ablutions among many African societies, one should not use it when eating and interacting with other people. For instance, it is not proper to shake hands using the left hand or pass something with the left hand to another person. By doing so, one may insult other people.

In this paper we focus on the issues concerned with cross-cultural communication. We assume that the successful act of communication depends "on a proper understanding of the underlying cultural scripts that participants bring with them into the global arena of cross-cultural communication" (Ameka and Breedveld 184). In the study we focus on the greeting practices among different African communities and intend to present a variety of cultural norms that govern greeting acts in various African language groups.

\section{THE FUNCTION OF GREETINGS}

The speech act of greeting is categorised as a type of expressive speech acts which are commonly used in our daily life. In general, we use greetings on a daily basis and it is one of a few language-related behaviours we actively teach our children.

\footnotetext{
${ }^{2}$ Although we should not forget that it is rude for people to talk with their mouth full.
} 
Greetings have been categorised among speech acts that are uttered in certain situations for particular purposes. According to Austin's Speech Act Theory (Austin; after Wei) greetings fall into the category of 'expressives' of illocutionary acts and therefore should not be taken literally. They are used as a sign of politeness. Therefore, there are usually fixed responses to the standard greeting formulas and the interlocutors are not expected to express one's real feelings, e.g. 'How are you?' in English is associated with an answer 'I'm fine' and not any other statement. One is not expected to give a negative answer or to elaborate on the real condition. In other words, a greeting should not be regarded as an instance of free conversation, all it shows is an attitude of the speaker, as it is used to express one's feelings toward the hearer.

Firth (30) sees greetings as "a system of signs that convey other than overt messages." The ability to understand the covert message by the interlocutors is assured by the routinization and conventionalized character of greeting expressions (Wei). Greetings have been also studied in the light of the assumptions of Brown and Levinson's politeness theory (Brown and Levinson; Wei) that employ the 'face' model developed by Goffman. The 'face' has been defined as the basic human desire that is shared by every member of the society. Politeness is understood as a universal concept which stipulates that participants in an interaction try to avoid causing discomfort or embarrassment to others. While the basic idea of the 'face' has been widely accepted, the concept of universal politeness theory has been questioned in numerous publications (cf. Tanaka; Mapunda and Sommer).

Nowadays, especially in the Western world, the role of greetings is neglected. People no longer greet each other properly because they are frequently in a hurry. When meeting a friend unexpectedly, one often only waves his or her hand or nods and goes about his or her business. In the Western culture we somehow tend to forget that a greeting is an expression of joy, attention and consideration in a proportionate way toward our family members and friends. When meeting a stranger, we are aware that making the first good impression is particularly important, so we put effort into our appearance eventually forgetting that it is a greeting that is crucial in creating the first good impression and setting a positive tone for the consecutive conversation. Addressing the hearer in an appropriate way, with proper behaviour and expected greeting formulas, fosters a foreigner's positive social experience in a foreign setting. 
Each community uses the greeting routine in everyday life, but greetings around the world vary. Greetings are conversational routines and not spontaneous speech acts applied by a given speech community when opening a conversation. There is often a pattern that has to be applied in a particular cultural context $-\mathrm{a}$ frame to be filled with words in a set of fixed expressions that should be used in a fixed order. The patterned routine varies depending on many factors, such as the context of the conversation, the relationship of the speakers, their status, gender, age and so on.

Other, non-verbal instances of behaviour may also accompany a greeting. Usually it is a handshake or a hug among very close friends, but it may also be a hand-kiss that is required from a man in reference to a woman in some societies. There are also other social or religious rules ${ }^{3}$ that, for example, forbid the shaking of hands, having any physical contact or at least consider it an instance of rude behaviour. When visiting a foreign country, one has to be aware of possible fundamental communication and discourse differences between one language and another. Greeting is a universal phenomenon but it is culture-specific at the same time.

\section{GREETINGS IN THE AFRICAN CONTEXT}

In the Kerebe language to visit and to greet are represented by the same word kubwacha (Kezilahabi), as it is in many other African languages. Both, visiting and greeting constitute an important component of everyday life and are categorised as part of the politeness phenomenon. Greetings in the African context are especially valued as they are perceived as one of the most essential aspects of culture (Yahya-Othman). A person who knows how to greet properly is regarded as someone who has good manners, who is polite and shows respect to others. Politeness is important as it "defines and sustains social hierarchies which are used to show respect and esteem" (Habwe 127). Therefore, in African cultures it is very important to greet people properly. Someone who fails to do so is regarded as uncaring, uneducated and ill-mannered, or even stupid. Such person may be also identified as a stranger who is not fluent in a language and is not familiar with the culture of the hosts. The performance of greetings differs from one society to another, and even within an ethnic group. However, there are some factors that govern communicative acts that are found across the continent.

\footnotetext{
${ }^{3}$ That cannot be separated realistically.
} 
In general, every language has some routine expressions used in social greetings. In Africa, every conversation starts with a greeting. Even if a conversation is short and held in a hurry, it should contain some sort of a greeting as an opening statement. Schleicher points out that in Africa greetings are not merely used to establish an atmosphere but they also communicate concern. Therefore, in Yoruba culture it is acceptable to talk about one's troubles as an answer to a general greeting báwo ni? 'how are you?' The same phenomenon was observed among the Ewe. Egblewogbe (9) states that "the salutations lead beyond the realm of phatic communion". Also, among Hausa, if one of the participants feels like complaining, the hearer will not be surprised, but will listen and sympathize with those who have problems (Chamo). Therefore, it is claimed that greetings in African languages communicate ideas, and not only create an atmosphere as it is accepted in Western culture, where greetings are mostly performed as acts of phatic communication.

Greeting expressions are taught at the beginning of every foreign language class, they are presented in textbooks and phrasebooks for beginner learners. It is easy to learn several fixed expressions that will impress local people. Although it may come as a surprise to many people, in most cases African greetings apply to a much wider variety of situations than do greetings in English or other European languages. Schleicher (336) notices that "there is no situation, condition, season, time, position, circumstance, or occasion for which the Yoruba do not have a greeting." A long list of Yoruba greetings contains, among others, a greeting for sitting down, greetings for trying your best, greetings for intelligence, greetings for working, greetings for meeting, greetings for standing up and even greetings for staying at home while one's loved one is away on a journey or left home or greetings for the children of an older person who has died. Traditional Tanzanian Ngoni greetings served a number of functions including "wanting to know about the situation of the collocutor, a marker of recognition and respect, an expression for requesting support when needed, and also a signal of community ties" (Mapunda and Sommer 66). In most cases African greetings carry strong culture-specific meanings and messages. They relate to issues concerned with religious beliefs, desire for children, style of living and concern for other people (Schleicher 342). A reprimand by elders is possible if someone is not able to offer or return a greeting.

Apart from vocabulary, in order to hold a proper conversation and to acquire fluent communicative skills, one needs to learn socio-cultural norms that govern communicative acts in a given language and in a certain social 
context. It is especially important in the African context as Africans attach great importance to respect for good manners and politeness, which ensure the maintenance of harmonious social relationships. This includes proper greeting strategies. One needs to be aware that the group takes precedence over the individual and it is very important to respect the hierarchy within the group, be it family or professional, and to show consideration to others. In most communities, the elders are especially respected as they symbolise wisdom and are closer in age to the ancestors. All this has an impact on discourse-related practices.

General rules of conversation in Africa are in some aspects similar and in others differ from those known in Western culture. In general, everywhere it is considered rude to interrupt when the other person is speaking. However, Zulu speakers make longer pauses before their statements, so one may get the impression that somebody has finished talking while he has not (Sommer and Lupapula). During a conversation, especially with one's senior, one should avoid eye contact as it is regarded as rude, challenging behaviour. The younger person is supposed to look down to show respect. In Western culture eye contact avoidance may be interpreted as if the person has something to hide. In African cultural perspective it is regarded as disrespectful to gaze at someone if the person is of a higher status (Ntuli).

Another behavioural form of showing respect to elders or those of a higher status is to keep one's head lower than that of the superior, by bowing, kneeling, squatting, and so on. In many traditional African societies elder people sit down before they engage in a conversation. In some settings, females and children are expected to kneel and men to squat when conversing with their elders. It is polite to be in a lower position than the elder person one is talking to, so the younger people may also sit during a conversation. In the South Bantu communities, a young person takes a seat right after entering a room where an elder person is present. Greetings at home may be carried out while participants are seated. As Mapunda and Sommer observe among the Ngoni, the differences in status and/or seniority may be expressed by the sitting arrangement. A senior participant may be seated on a chair, and a junior speaker, while initiating a greeting, may involve movements such as crouching, squatting and sitting down on the floor. This is contradictory to Western culture, where people first have to be offered a seat before they can sit down.

There are different factors that influence the choice of greeting formulas and the greeting act processes. The greeting system may be described as a series of choices one has to make based on the social context of the 
conversation. Such social factors as age, kinship, acquaintance, rank, as well as setting and time of the day may be taken into consideration. Some of the factors are described below.

\section{THE CONTEXT OF GREETINGS}

In Africa everyone greets everyone. It does not matter if we know the other person or not. Everyone deserves to be greeted. People greet each other whenever they meet, and the same individuals may exchange greetings several times a day. For example, Tanzanian Ngoni, as well as the Akan of Ghana, the Baatombu of Benin, and the Ewe greet each other regardless of whether they know each other or not (Adukpo et al.; Agyekum; Mapunda and Sommer; Schottman). Chamo, while studying greetings among Hausa, observes that it is unusual when two Hausa people who know each other pass by without exchanging some form of a greeting. The same has been observed among Igbo (Nwoye) and Yoruba. Schleicher noticed that if two people in a Yoruba community pass by without greeting one another, others may suspect that they are upset with each other. Among Setswana, Bagwasi (96) noted that "in the old days, young people were expected to greet every adult that they met, regardless of whether they knew them or not." The communicative practices change as will be discussed further. Greetings, but phatic in function, are also exchanged with strangers in order to show politeness and welcome in most African communities (Agyekum; Akindele; Chamo; Dzameshie; Mapunda and Sommer; Nwoye).

Greetings may vary depending on the formal or informal contexts of the situation. The formal situations are more often accompanied by the use of special expressions and honorific address forms. Greetings may be also timebound or time-free. Time-bound greetings relate to the time of the day or other time related occasion, like traditional or religious festivals. The various periods of the day call for particular greetings, as for morning, noon, afternoon or evening. There may be also greetings that reflect the various occasions and activities around which communication may be initiated. These may be work, eating, travelling, visiting friends and relatives, visiting sick persons, but also child births, deaths and funerals, weddings, and so on. 


\subsection{Who Greets Whom?}

In most African communities, the one who initiates greetings usually depends on social hierarchy that may be based on different criteria, such as age, gender and social status. Equality is non-existent. The younger will be always lower in a social hierarchy than the elder ones, a woman is usually considered slightly inferior to her husband. In general, it is the younger who initiates a greeting, the female, or the one with the lower status, as an employee to an employer, a child to a parent. If a person enters a gathering of people, the one who enters is expected to greet the group, the guest should greet the host. But in this case, it may happen that two rules could come into conflict.

In situations where age and gender are in conflict, such as an older woman and a younger man, the act differs among communities. In most cultures, it is the age that is more relevant in terms of who greets whom first (Agyekum; Akindele; Bagwasi; Nwoye; Schottman). In such a case, age will be of a higher status and a younger man will greet a woman. However, it is not always the case. In some African communities the gender (male over female) is superior to age. For example, in the Sukuma family hierarchy gender (male) is more important and assumes superiority than age (Batibo). On the contrary, among the Swahili it is age that has a greater importance than gender. As a result, a girl who is elder than her brother in the Sukuma family would greet her brother kneeling respectfully, even if speaking Swahili. Among the Swahili, it is the younger male sibling who would be the one to show respect to an elder female and greet her respectfully. The same applies to Hausa and Yoruba- a woman is expected to greet a man before he greets her if the man is older, but if she is older, he is expected to greet her as a token of respect for her age.

There may be some exceptions to this rule. If two people are approaching each other, it may be expected that whoever sees the other person first is the one who initiates the greeting, whether young or old, male or female, as in Yoruba. If both people see one another at the same time, it is respectful for the younger one to immediately initiate greetings (Schleicher).

Among the Setswana ethnic groups, some contradictory behaviours have been noticed. Among the Bangwaketse, when a younger and an older person meet away from home, the younger person has to initiate the greeting. However, when the participants meet at home the greeting is initiated by whoever is arriving. Among the Bangwato, it is always the younger person who initiates the greetings, even if the older person is coming as the visitor (Bagwasi). 
Even if a younger/inferior person initiates the greeting, the verbally active role is respectively assigned to the elder who takes over the conversation and asks about the welfare of the other participant. In some West African communities, the younger participant no longer has the right to speak (Schottman). In other cultures, such as Swahili, the elder has an active role but the younger person should also be active and is allowed to ask questions as greeting continues. However, in the Wolof culture, the person of lower status initiates the greeting and asks questions while the other only responds (Schleicher).

Among the Muslims, it is the younger person who initiates the greeting as a way of showing respect to the elder people. The elderly person is then expected to reply in order to show appreciation. In general, it is impolite for the younger person to interrupt when the elderly person is talking, but, as it was already mentioned, during the act of exchanging greetings, the younger person is expected to take active part in a conversation as well. Unlike in Yoruba culture, in the Hausa culture a younger person may ask certain questions of elder persons in the greeting sequence without the latter stimulating him to do so (Chamo). However, there may be certain restrictions as to the topics that may be covered. Bagwasi noticed among the Bangwato ethnic group that an elderly person may talk about their health but one should not ask about it.

In the case of status, it is possible that professional rank precedes age and is a criterion of a greeting initiation.

When the younger/inferior person initiates greetings it is very important that she/he uses the right expressions. If not, the elder, offended interlocutor may react and demand the right form of address (Omar).

If two people are the same age, every one of them can initiate a greeting. The variety of possible greeting forms is also much wider than in the case of the younger/elder meeting.

It is worth mentioning that there are also some communities, like Ewe, where there is no restriction on who should initiate the greeting based on a status or age. A young person may greet an elder, but it is also possible for an elder to initiate an interaction. In general, it is a visitor who should start the conversation (Adukpo et al.).

\subsection{The Length Of Greetings}

The length of greetings depends on many factors and it may vary whether it takes place in urban or rural environment, or depending on the age of the 
people who are communicating. In general, greetings in rural areas and among elders tend to be longer.

Greetings can be lengthened as the time and circumstances permit, with the participants taking turns. If persons are not in a hurry and have time to spare, the greeting may be more elaborate. The participants may intentionally ask each other about the well-being, the welfare of the household and the extended family before proceeding to other matters.

The length of a greeting may be also proportional to the length of time since the last meeting. The longer the participants have not seen each other, the longer the greeting will last (Agyekum; Mapunda and Sommer).

The other factor is the importance of the relationship. Close friends will exchange longer greetings than mere acquaintances. But it is not only the length that matters but also the eagerness and involvement of the participants. If a greeting is too short the other participant may feel offended. Omar estimated that an average length of a greeting in Swahili takes five turns. Each turn consists of a question and a response. The number of turns may differ depending on the relationship of the participants. The closer they are the longer the greeting is expected to be. The situational context also mattersthe more formal it is, the shorter the greeting will be. Therefore, the greeting will be longer between two friends meeting at home than the one between a customer and a clerk at some office.

It is very important that both participants engage in a greeting. If one of them does not respond to questions or does not ask any questions himself, the conversation may come to an end earlier than expected.

It has been also observed that the participants who represent a higher status are the ones who more often determine the length of greetings (Schottman).

\subsection{Greeting Taboos}

In African communities there are some taboos associated with greetings. In the West African communities, such as Akan and Ewe, it is a taboo to greet while on the way to the toilet, since the person is regarded as unclean. One may only greet and be greeted on the way back (Agyekum; Dzameshie; Egblewogbe). Among the Ewe one should also not greet before a person washes his or her mouth in the morning (Egblewogbe). Among the Baatombu of Benin some greeting constraints are imposed on the ones who are mourning or in the period of initiation. Also, a young mother carrying a child will not answer questions about her child's health (Schottman). Nyakusa bride refuses to greet men during the marriage ritual (Walsh). 
There are also principles in personal naming strategies. In African societies personal names have a symbolic value and are of a greater importance than in Western culture. In most cases they represent culture-bound content and it is believed that names are worthy of respect. A name identifies the person who bears it, often points to the family and the whole society and its values (Ubahakwe; after Ameka and Breedveld). In general, the use of names in an everyday communication is therefore avoided. Especially, when one is addressing adults alternative address strategies are often employed. These are titles based on religious or occupational roles, kinship terms or other honorifics. It is also a very popular practice to use teknonyms or parenthood titles. In many communities, as among the Swahili, a woman is often called by the name of her first-born child, for example Mama Ali 'the mother of Ali.' Popular forms of address in Swahili include such honorifics as bibi 'lady', bwana 'gentleman/sir', mzee 'elder person', but also kinship terms, such as baba 'father/sir', mama 'mother/lady', ndugu 'brother/sister/fellow man.' It is worth observing that Swahili honorifics are used as often in formal as in informal situations. Akindele (11) confirms naming taboo for Sesotho: "[i]t is very rare to find people greeting each other by using first names, last names, titles plus last name or titles only". Instead terms referring to mother, $\mathrm{mm}$ ' $e$, and father, ntate, are used in an extended sense of 'sir' and 'madam.'

Not all communities share the same restrictions and Hausa speakers in most cases address their interlocutors by their first name (Chamo).

\subsection{Non-Verbal Communication}

Greetings are rituals which consist of verbal and non-verbal acts (Firth). In traditional African communities the non-verbal communication plays a very important role equally to the verbal one. Ntuli (21) observes that "a lack of understanding of other people's culture and nonverbal behaviours can cause misunderstandings and even conflict." Every culture uses non-verbal behaviour, such as gestures, which may differ from those of other cultures, thus it is important to know at least the basic norms of behaviour of the people we are going to communicate with. There are some rules that one has to obey. In the African context, beckoning to someone, pointing at someone with one finger, looking someone straight in the eyes, passing things - especially food - with the left hand and so on, is unacceptable.

The most popular behaviour during a greeting is a handshake. In many communities, such as Akan, Yoruba, Ewe, South Bantu ethnic groups, and Swahili, a handshake is regarded as a part of a greeting. In many cultures it is 
the adult who initiates the handshaking procedure (Egblewogbe; Schleicher and Moshi). On the other hand, in Muslim societies, such as Hausa, men prefer not to shake hands with women.

When the ones who greet are of similar age, they are free to use verbal expressions and gestures they both feel comfortable with in order to show friendship and solidarity.

It is a rule that in order to show respect, Africans bow their heads to people who are elder than them or to superiors. The act of kneeling or squatting is especially popular in West Africa. Yoruba girls who follow traditional rules kneel down to greet an adult while the boys prostrate themselves. The Hausa squat to greet one another, Ibo children bow when greeting a parent (Schleicher and Moshi). Among the Ewe, a woman and a girl bows or slightly bends her knees when greeting a man or somebody, also a woman, who is elder or of a higher social status. Boys bow while putting their hands behind (Egblewogbe). But also among the Setswana communities women show respect to their men or elder women addressees by bending a knee during the greeting. Men show respect to other men who are socially superior to them by taking off their hats or stooping (Bagwasi). Schottman illustrated with pictures all kinds of greeting practices as far as kneeling, bowing and squatting among the Baatombu of Benin are concerned.

Kneeling is not as popular in East Africa and, for example, it does not feature in Swahili greetings but it is practiced among other traditional communities, such as Ngoni and Sukuma. Additionally, in Swahili greetings, a handshake is not required and especially among Muslims, where a handshake is possible between husband and wife but not otherwise.

It has been observed that in modern societies, especially in urban areas, young women more often shake hands and hug when greeting (Chamo). Girls in East Africa, e.g. in Kenya, kiss each other on the cheeks.

In many communities, both in West and East Africa, people are expected to use both hands for shaking. It is practiced among the Ewe when greeting chiefs and elders (Egblewogbe). The person initiating a greeting offers his or her right hand first, followed immediately by the left hand. The participants may hold their hands during greetings, or even during the whole conversation.

\subsection{Modernisation}

Politeness-related strategies change over time. Nowadays, as a result of contact with Western culture, Africans tend to abandon the traditionally valued acts of greetings. Especially in urban areas it may be observed that people do 
not pay attention to greetings anymore. They greet briefly, often with the use of expressions from languages of wider communication, such as English or Swahili, and greetings are restricted only to those who are known. Moreover, young people are not familiar with traditional greetings at all.

In urban settings young people more rarely greet the elder people than in villages. While researching greeting acts among the Sesotho, Akindele observed that in fact it was the elder ones that greeted the younger ones more often than vice versa.

Bagasi observes that nowadays among the Bangwaketse young people expect adults to initiate greetings when they are visiting. They also feel comfortable to ask adults how they are doing, what may be perceived as a new development. The author assumes that it came about as a result of their interaction with other non-Setswana ethnic groups.

Agyekum reports that most Akan people living in the cities use English greetings, such as Good morning, instead of traditional Akan ones. Mapunda and Sommer observed a similar trend among Tanzanian Ngoni, who eagerly switch to Swahili. There are young people in the cities, who do not know the traditional greetings at all. They consider English, or other power languages, like Swahili or Zulu, to be more prestigious and abandon their native languages and traditions in favour of dominant languages and cultures. The tendency to prefer dominant languages is viewed as lack of respect by elders whereas the younger generations regard it as a sign of modernisation and as a reflection of social changes that have been taking place in the communities. While traditional greetings and other customs are considered a sign of past, cultivated only by old-fashioned, uneducated villagers. On the other hand, elder people, especially in the rural areas, resist this kind of modernity and appreciate and still practice greetings as if they wanted to preserve the traditional customs.

Among the young, even the traditional greetings in their native languages have new, modern variants. Due to contact with majority languages, traditional greetings tend to be brief and there is a widespread use of codeswitching. These consist of one or two turns of question-response phrases. In Swahili these would be one-word expressions such as Sema? 'what do you say?', Mambo? 'how are things?', Vipi? 'what's up?', followed by one-word responses, such as Poa, Safi, Salama, or Freshi, all meaning 'all right'. The greeting are brief and dynamic.

Furthermore, some of the traditional practices, such as kneeling, bending and so on, are no longer strictly adhered to or even abandoned completely. 
On the other hand, there are also other consequences of a language shift. When minority language speakers shift to dominant languages or speak them as second or primary languages, they still transfer their traditional native language cultural norms into dominant language communication. In Swahili, the term reserved for an elder brother is kaka, the younger one is called mdogo. In the Sukuma community an elder sister while speaking Swahili will call her younger brother kaka as it would be disrespectful to call him mdogo wangu meaning 'my younger'. Among the Sukuma it is the gender that overrides age and the sister adheres to Sukuma norms even when using another language. Additionally, she would greet her brother kneeling down, a thing which is not expected among the Swahili (Batibo). The language shift, in this case from Sukuma to Swahili, is not always accompanied with the assimilation of the socio-cultural norms. Therefore, in case of the dominant languages, such as Swahili, it is difficult to indicate clearly what are its pure socio-cultural norms and which have been adopted from native cultures of its speakers.

\section{CONCLUSION}

In Africa the function of greetings is not only to start a conversation, but also to establish and to sustain good interpersonal relations with others. It is important to greet. Greeting is regarded as a social duty and personal responsibility. It expresses concern for one another and for the society as a whole. While greeting the participants acknowledge group solidarity and fellow-feeling, but what is even more important, respect towards each other.

Refusal to greet, or greeting in an inappropriate way may cause offence and may lead to a negative attitude towards the person involved. As a consequence, it may be interpreted in terms of denial of social recognition. Such a person may be regarded as rude, proud, uncaring or even recognised as a stranger.

Each aspect of a greeting is equally important. The verbal and non-verbal expressions used in greetings denote the social relationship between the participants. Although the verbal expressions used in greetings are routinized, they carry a culture-specific content and have social implications. There is no homogenous act of greeting across all African communities. Every culture is governed by its own rights, and this remark also applies to greetings. The young and elderly communicate differently and they are likely to perform 
greetings differently as well. In most cases it is the social hierarchy that plays an important role in discourse schemata. Nevertheless, possible variations in the patterns and strategies of greetings between various communities cause a potential for misunderstanding of politeness among the groups.

In African communities the main factors that govern greetings are age and gender. In most cases it is the age that is superior to gender as of who initiates the greeting. So, a young woman will greet a man, but if a woman is elder, then she will be greeted by a man. The other important factors are mutual interest of the participants and desire to maintain the conversation.

One has to be aware that every speaker is acquainted with his or her own cultural behaviour and he or she transmits it to conversations that may be held in other languages. Knowing the norms that govern communication in other societies will enable successful cross- or intercultural communication, since even such a universal communicative act as greeting a person has the pragmatic value of a given culture.

\section{BIBLIOGRAPHY}

Adukpo, John, et. al. "Greetings or Information Exchange in Ewe Community." Journal of African Studies and Ethnographic Research, vol. 1, no. 1, 2019, pp. 20-35.

Agyekum, Kofi. "The Pragmatics of Akan Greetings.” Discourse Studies, vol. 10, no. 4, 2008, pp. 493-516.

Akindele, D. "Lumela/Lumela: A Socio-Pragmatic Analysis of Sesotho Greetings." Nordic Journal of African Studies, vol. 16, no. 1, 2007, pp. 1-17.

Ameka, Felix K. and Anneke Breedveld. "Areal Cultural Scripts for Social Interaction in West African Communities.” Intercultural Pragmatics, vols. 1/2, 2004, pp. 167-187. DOI: 10.1515/ iprg.2004.1.2.167.

Austin, John L. How to Do Things with Words. Harvard University Press, 1962.

Bagwasi, Mompoloki. "The Effect of Gender and Age in Setswana Greetings." Southern African Linguistics and Applied Language Studies, vol. 30, no. 1, 2012, pp. 93-100. DOI: 10.2989/ 16073614.2012.693717.

Batibo, Herman. "The Inter-cultural Dimension in the Use of Languages of Wider Communication by Minority Language Speakers." Journal of Multicultural Discourses, vol. 4, no. 2, 2009, pp. 89-102. DOI: 10.1080/17447140802691716.

Chamo, Isa. "Pragmatic Differences in Greetings: A Comparative Study of Hausa and English." BAJOLIN, vol. 1, no. 2, 2015, pp. 258-274.

Dzameshie, A. "The Forms, Functions and Social Value of Greetings Among the Ewes." New Directions in Ghanaian Linguistics, eds. Ameka, Felix K. and E. K. Osam, Black Mask, 2002, pp. 381-408. 
Egblewogbe, E. "Social and Psychological Aspects of Greeting among the Ewes of West Africa." Research Review, vol. 6, no. 2, 1990, pp. 8-18.

Firth, Raymond. "Verbal and Bodily Rituals of Greeting and Parting." The Interaction of Ritual, eds. Jean Sibil La Fontaine, Tavistock Publications, 1972, pp. 1-38.

Goddard, Cliff, and Anna Wierzbicka. "Cultural Scripts: What Are They and What Are They Good for?” Intercultural Pragmatics, vol. 1, no. 2, 2005, pp. 153-166. DOI: doi.org/10.1515/ iprg.2004.1.2.153.

Goffman, Erving. Interaction Ritual: Essays on Face to Face Behavior. Aldine Publishing Company, 1967.

Habwe, John. "Politeness Phenomena: a Case of Kiswahili Honorifics." Swahili Forum, vol. 17, 2010, pp. 126-142.

Kezilahabi, E. "Greetings: A case study from the Kerebe." African Folklore: An Encyclopedia, eds. Philip M. Peek and Kwesi Yankah, Routledge, 2004, pp. 157-167.

Mapunda, Gastor, and Gabriele Sommer. "When Shikamoo Mama/Baba Replaces Tukuwoni Mawu/Dadi: An Account of Shifting Access Rituals among the Ngoni of Tanzania." Linguistik Online, vol. 84 (5/17), 2017, pp. 63-90.

Ntuli, Cynthia D. "Intercultural Misunderstanding in South Africa: An Analysis of Nonverbal Communication Behaviour in Context." Intercultural Communication Studies, vol. 21, no. 22, 2012, pp. 20-31.

Nwoye, Onuigbo G. "An Ethnographic Analysis of Igbo Greetings." African Languages and Cultures, vol. 6, no. 1, 1993, pp. 37-48.

Omar, Alwiya. "How Learners Greet in Kiswahili: A Cross Sectional Survey." Pragmatics and language learnin, eds. L. F. Bouton and Y. Kachru, University of Illinois, 1991, pp. 59-73.

Schleicher, Antonia. "Using Greetings to Teach Cultural Understanding." The Modern Language Journal, vol. 81, no. 3, 1997, pp. 334-343.

Schleicher, Antonia, and Lioba Moshi. The Pedagogy of African Languages: An Emerging Field. Ohio State University, 2000.

Schottman, Wendy. "The Daily Ritual of Greeting among the Baatombu of Benin." Anthropological Linguistics, vol. 37, no. 4, 1995, pp. 487-523.

Sommer, Gabriele, and Abel Lupapula. "Comparing Address Forms and Systems: Some Examples from Bantu." Selected Proceedings of the 42nd Annual Conference on African Linguistics, eds. M. Marlo et al., 2012, pp. 266-277.

Tanaka, Lidia. Gender, Language and Culture: A Study of Japanese Television Interview Discourse. John Benjamins Publishing Company, 2004.

Walsh, Martin. "Nyakusa Greetings." The Cambridge Journal of Anthropology, vol. 7, no. 3, 1982, pp. 31-44

Wei, Lie. "The Functions and Use of Greetings." Canadian Social Science, vol. 6, no. 4, 2010, pp. 56-62

Wierzbicka, Anna. "Russian Cultural Scripts: The Theory of Cultural Scripts and Its Application." Ethos, vol. 30, no. 4, 2002, pp. 401-432.

Yahya-Othman, Saida. “Aren't You Going to Greet Me? Impoliteness in Swahili Greetings.” Text, vol. 15, no. 2, 1995, pp. 209-227. 


\section{CULTURAL NORMS OF GREETINGS IN THE AFRICAN CONTEXT}

\section{S u m m a r y}

Knowledge of a foreign language facilitates communication. In order to be fluent in a foreign language, it is not enough to learn its words and grammatical rules, but one has to also be aware that there are additional, culture-bound norms that govern communication practices among various language groups. Even if one is not fluent in a foreign language, it is possible to make communication successful by applying appropriate non-verbal behaviour. In this article, I present communicative culture-related greeting rules among different African communities. I focus on the main factors that govern acts of greeting in different African languages.

Key words: greetings; African languages; African communities; verbal communication; non-verbal communication.

\section{KULTUROWE NORMY POZDROWIEŃ W KONTEKŚCIE AFRYKAŃSKIM}

\section{Streszczenie}

Znajomość języków obcych pomaga w nawiązywaniu kontaktów. Do biegłej komunikacji nie wystarcza znajomość słownictwa i reguł gramatycznych danego języka, ale równie ważne są kompetencje socjokulturowe, czyli znajomość norm dyskursu. Nawet jeśli nie jesteśmy biegli w danym języku, stosując właściwe normy konwersacji i zachowania niewerbalne, możemy wpłynąć na przebieg rozmowy. W artykule przybliżam kulturowe zasady komunikacji w kilku językach afrykańskich na przykładzie pozdrowień.

Słowa kluczowe: powitania; pozdrowienia; języki afrykańskie; grupy etniczne Afryki; komunikacja werbalna; komunikacja niewerbalna. 